\title{
Kemampuan membaca peta Rupa Bumi Indonesia (RBI) Skala 1:25.000 oleh mahasiswa Pendidikan Geografi Universitas Negeri Malang
}

\author{
Rudi Hartono* \\ *Jurusan Geografi, Fakultas Ilmu Sosial, Universitas Negeri Malang
}

\begin{tabular}{l}
\hline \hline INFO ARTIKEL \\
\hline Riwayat Artikel: \\
Dikirim: $8-3-2018$ \\
Disetujui: $25-7-2018$ \\
Diterbitkan: $31-1-2019$ \\
\hline
\end{tabular}

Kata kunci:

Peta Rupa Buni Indonesia

(RBI); Membaca Peta

\begin{abstract}
ABSTRAK
Abstract: In geography learning, especially in Cartography courses students are asked to read Indonesian topographic maps (RBI). However, the reading does not show satisfactory results. Analysis of the results of the practicum reading the RBI map, especially the 1: 25,000 RBI, shows that the results have many variations in the level of truth. Therefore, it is necessary to do research on the level of ability to read the RBI map by the new / 2016 geography education students. This study was intended to determine the level of ability to read the RBI map by geography education students. Thus, this research is ex post facto for their ability to read maps. How to analyze the ability to read maps is done by giving scores on student answers. To achieve this goal, a sampling of the RBI map of the geography education students was conducted by 60 students in the 2016 class, following the rules: (a) The RBI map must read at least its map attributes, (b) RBI maps must read the location information, (c) Map The RBI must read information about the characteristics of the region it describes. The results showed that the high ability category ranked first, namely as many as 32 people (53\%), moderate ability 24 people (40\%), low ability 3 people (5\%), and very low ability 1 person (2\%). This result is not satisfactory because only $53 \%$ are highly capable of reading the RBI map. This is useful for lecturers, especially the problems faced by new students of Geography Education in extracting information from an RBI map. In addition, this research indirectly provides benefits for students, they can learn and use maps more precisely.
\end{abstract}

Abstrak: Dalam pembelajaran geografi, khususnya mata kuliah Kartografi mahasiswa diminta membaca peta rupabumi Indonesia (RBI). Akan tetapi, pembacaan itu tidak menunjukan hasil yang memuaskan. Analisis terhadap hasil praktikum membaca peta RBI, khususnya RBI skala 1:25.000, menunjukan bahwa hasil tersebut memiliki banyak variasi tingkat kebenarannya. Oleh karena itu, perlu dilakukan penelitian tingkat kemampuan membaca peta RBI oleh mahasiswa pendidikan geografi angkatan baru/2016. Penelitian ini dimaksudkan untuk mengetahui tingkat kemampuan membaca peta RBI oleh mahasiswa pendidikan geografi. Dengan demikian, penelitian ini bersifat ex post facto atas kemampuan mereka dalam membaca peta. Cara analisis terhadap kemampuan membaca peta dilakukan dengan pemberian skor terhadap jawaban mahasiswa. 
Jurnal Pendidikan Geografi:

Kajian, Teori, dan Praktik dalam Bidang Pendidikan dan Ilmu Geografi

Tahun 24, Nomor 1, Jan 2019, Hal 25-30

\section{Alamat Korespondensi:}

Rudi Hartono

Jurusan Geografi

Universitas Negeri Malang

Jalan Semarang No. 5 Malang

E-mail: rudi.hartono.fis@um.ac.id

Untuk mencapai tujuan tersebut, maka dilakukan sampling pembacaan peta RBI terhadap mahasiswa pendidikan geografi sebanyak 60 mahasiswa angkatan 2016, dengan mengikuti aturan: (a) Peta RBI harus terbaca minimal atribut petanya, (b) Peta RBI harus terbaca informasi lokasinya, (c) Peta RBI harus terbaca informasi karakteristik wilayah yang digambarkannya. Hasil penelitian menunjukan kategori kemampuan tinggi menempati urutan pertama, yaitu sebanyak 32 orang (53\%), kemampuan sedang 24 orang (40\%), kemampuan rendah 3 orang $(5 \%)$, dan kemampuan sangat rendah 1 orang $(2 \%)$. Hasil ini belum memuaskan karena hanya 53\% yang berkemampuan tinggi dalam membaca peta RBI. Ini bermanfaat untuk dosen, terutama masalah yang dihadapi para mahasiswa baru Pendidikan Geografi dalam mengekstrak informasi dari suatu peta RBI. Selain itu, penelitian ini secara tidak langsung juga memberikan manfaat bagi mahasiswa, mereka dapat mempelajari dan menggunakan peta secara lebih tepat.

\section{PENDAHULUAN}

Peta merupakan media yang sangat penting dalam pembelajaran geografi, berkaitan dengan hal itu dosen dituntut menggunakan media peta dalam setiap perkuliahan. Namun pada kenyataannya masih banyak dosen yang kuang mengeksplor keguanan pata RBI sehingga pembelajaran geografi masih belum berhasil secara optimal.

Sumaatmadja (1996) mengatakan bahwa peta sebagai media utama pengajaran geografi akan sangat mempengaruhi pembentukan citra, konsep peserta didik melalui peningkatan kemampuan kognitif, afektif, dan psikomotornya. Dalam melakukan peningkatan kemampuan tersebut, dilaksanakan melalui proses yang terjadi pada diri masing-masing mahasiswa. Proses dimulai dari tahap pengenalan, pembacaan peta (map reading), pemilihan, dan pembuatan peta.

Berdasarkan studi awal di lokasi penelitian (jurusan geografi FIS UM), diperoleh gambaran bahwa hasil belajar Kartografi memiliki nilai sedang terutama apabila dihadapkan pada soal-soal yang berkaitan dengan ekstraksi ukuran dari peta RBI. Kenyataan tersebut apabila diamati disebabkan kemampuan mahasiswa dalam membaca peta masih perlu ditingkatkan, terutama dalam hal: (1) mengartikan simbol-simbol yang ada pada peta RBI, (2) orientasi peta (menentukan arah pada peta), (3) mengungkapkan informasi/analisis simbol yang ada pada peta. Apabila permasalahan ini teratasi, maka mahasiswa akan mudah dalam mengerjakan soal-soal yang berkaitan dengan peta RBI dan peta lain pada umumnya.

\section{METODE}

Penelitian ini berifat diskriptif dengan analisis skoring terhadap jawaban yang diberikan oleh mahasiswa. Sebanyak 60 mahasiswa diambil secara acak sebagai rsponden dengan membatasi angkatan mereka, yaitu mahasiswa jurusan Pendidikan Geografi angkatan 2016. Sesuai dengan rancangan penelitian, terdapat dua instrumen pokok yang 
Jurnal Pendidikan Geografi:

Kajian, Teori, dan Praktik dalam Bidang Pendidikan dan Ilmu Geografi

Tahun 24, Nomor 1, Jan 2019, Hal 25-30

digunakan untuk mengumpulkan data, yaitu lembar jawaban, dan peta RBI contoh yang harus dibaca oleh mahasiswa. Lembar jawaban digunakan untuk mengumpulkan data mengenai apa yang harus dijawab oleh mahasiswa. Sementara itu, peta RBI contoh digunakan untuk mengukur sikap mahasiswa yang terkait dengan motivasi dan minat selama proses pembelajaran melalui analisis materi soal tentang menginterpretasi dan menganalisis peta RBI.

Pembuatan soal yang diberikan kepada mahasiswa mengacu pada teori penggunaan peta yang terdiri dari tiga tingkatan yaitu: membaca peta (M1), menginterpretasi peta (M2), dan menganalisis peta (M3). Antara jawaban M1, M2, M3 diberi bobot sesuai dengan tingkat kesulitan tahapan penggunaan peta.

a. Membaca Peta RBI (M1)

Tabel 1. Skor Membaca Peta RBI

\begin{tabular}{llcc}
\hline No. & \multicolumn{1}{c}{ Variabel } & Skor Min. & Skor Max. \\
\hline 1 & $\begin{array}{l}\text { Harus bisa menuliskan format baku peta RBI dan cara pemberian nomer } \\
\text { indeks peta. }\end{array}$ & 0 & 10 \\
\hline 2 & $\begin{array}{l}\text { Menjelaskan judul, nomer indek peta, tipe skala yang digunakan, wilayah } \\
\text { administrasi yang tergambar pada peta, cara membaca koordinat } \\
\text { titik/tempat, jenis proyeksi yang dipakai dan sumber data peta RBI. }\end{array}$ & 0 & 10 \\
\hline 3 & $\begin{array}{l}\text { Membaca simbul peta yang terdiri dari informasi: penggunaan lahan dan } \\
\text { vegetasi, } \\
\text { Simbul batas administrasi, permukiman, objek perhubungan dan } \\
\text { transportasi, objek hidrologi/tubuh perairan, relief, dan toponimi objek }\end{array}$ & 0 & 10 \\
& Jumlah
\end{tabular}

b. Menginterpretasi Peta RBI (M2):

Tabel 2. Skor Menginterpretasi Peta RBI

\begin{tabular}{clcc}
\hline No & \multicolumn{1}{c}{ Variabel } & Skor Min. & Skor Max. \\
\hline 1 & Menentukan arah dengan cara azimuth dan bearing & 0 & 5 \\
\hline 2 & Mengukur arah, misal arah suatu kota dilihat dari kota lain & 0 & 5 \\
\hline 3 & Mengukur suatu satuan jarak dan luas pada peta & 0 & 5 \\
\hline 4 & Menentukan tinggi suatu titik dan beda tinggi dua titik atau lebih & 0 & 5 \\
\hline 5 & Menentukan kemiringan lereng suatu lahan & 0 & 5 \\
\hline 6 & Memperkirakan volume tanah atau air genangan/waduk & 0 & 5 \\
\hline & Jumlah & & \\
\hline
\end{tabular}

c. Menganalisis Peta RBI (M3):

Tabel 3. Skor Menganalisis Peta RBI

\begin{tabular}{llcc}
\hline No & \multicolumn{1}{c}{ Variabel } & Skor Min. & Skor Max. \\
\hline 1 & Membuat/menarik batas sutau DAS atau Sub-DAS & 0 & 10 \\
\hline 2 & Menentukan orde sungai & 0 & 10 \\
\hline 3 & Menduga tipe bentuklahan & 0 & 10 \\
\hline 4 & Menduga bahaya alam yang mungkin muncul pada suatu lahan & 0 & 10 \\
\hline & Jumlah & &
\end{tabular}

a. Penilaian akhir

Skor Akhir $=[0,3$ M1 + 0,3 M2 + 0,4 (M3)/10]x 100 
Jurnal Pendidikan Geografi:

Kajian, Teori, dan Praktik dalam Bidang Pendidikan dan Ilmu Geografi

Tahun 24, Nomor 1, Jan 2019, Hal 25-30

b. Klasifikasi Tingkat Kemampuan Penggunaan Peta RBI

Tabel 4. Klasifikasi Tingkat Kemampuan Penggunaan Peta RBI

\begin{tabular}{lcc}
\hline No. & Kelas Kemampuan & Skor \\
\hline 1 & $0-25$ & Sangat rendah \\
\hline 2 & $26-50$ & Rendah \\
\hline 3 & $51-75$ & Sedang \\
\hline 4 & $>75$ & Tinggi \\
\hline
\end{tabular}

\section{Kemampuan Membaca Peta RBI}

\section{HASIL DAN PEMBAHASAN}

Berdasarkan data penelitian diketahui bahwa mahasiswa pendidikan geografi yang bisa menjawab dengan benar pertanyaan pada isian membaca peta sejumlah $32(53,33 \%)$ mahasiswa. Ini berarti bahwa separo lebih responden mampu menggambarkan format baku peta RBI, membaca nomer indeks peta, menjelaskan judul, nomer indek peta, tipe skala yang digunakan, wilayah administrasi yang tergambar pada peta, cara membaca koordinat titik/tempat, jenis proyeksi yang dipakai dan sumber data peta RBI. Membaca simbul peta yang terdiri dari informasi: penggunaan lahan dan vegetasi, Simbul batas administrasi, permukiman, objek perhubungan dan transportasi, objek hidrologi/tubuh perairan, relief, dan toponimi objek.

Membaca peta RBI merupakan kemampuan pertama yang harus dikuasai dalam menggunakan peta itu. Membaca peta mencakup kemampuan menentukan daerah peta dan kedudukan peta dalam seri peta RBI yang jumlahnya ratusan lembar. Kemudian berlanjut pada membaca informasi tepi peta berupa judul, nomer lembar peta, skala, proyeksi, tanda arah, sumber data peta serta legenda dan terkahir membaca simbul-simbul yang tergambar pada peta.

Merujuk pada jawaban mahasiswa kolom isian dalam menggambarkan lay out peta yang dilakukan mahasiswa, terdapat $36(76,6 \%)$ mahasiswa yang benar, $15(25 \%)$ mahasiswa menjawab setengah dan terdapat $8(13,33 \%)$ mahasiswa yang sama sekali tidak bisa mennggambarkan format baku/lay out peta RBI 1:25.000, namun masih mampu membaca simbul peta.
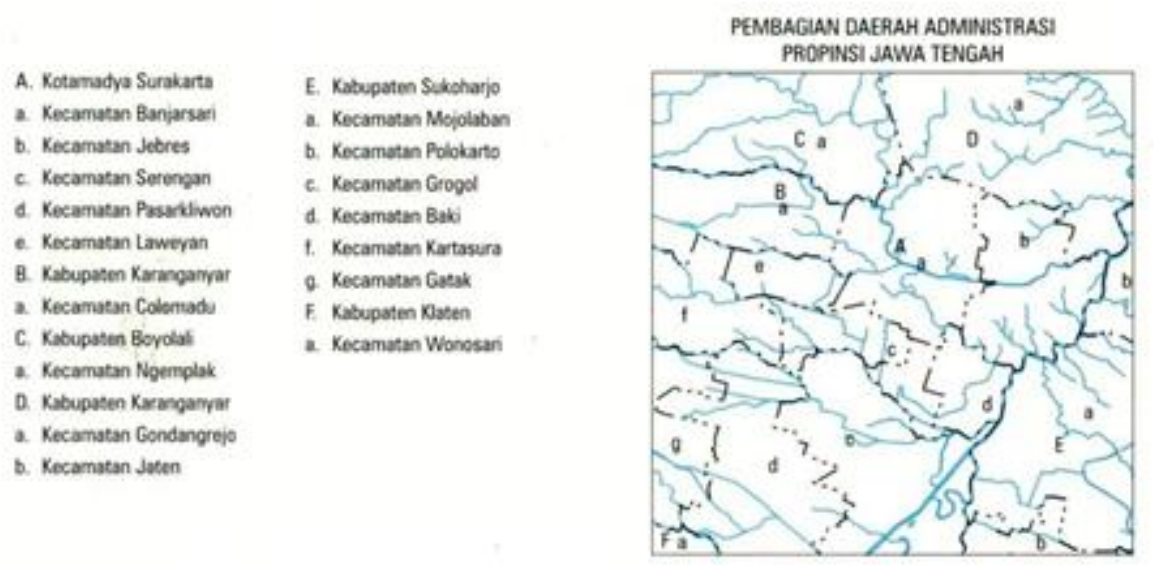

Gambar 1. Contoh gambar lokasi administrasi pada peta RBI yang dibaca oleh mahasiswa

\section{Menginterpretasi Peta RBI}

Menginterpretasi peta merupakan kegiatan menentukan arah azimuth, mengukur jarak, menentukan tinggi dan beda tinggi titik, menentukan kemirinan lereng dan 
Jurnal Pendidikan Geografi:

Kajian, Teori, dan Praktik dalam Bidang Pendidikan dan Ilmu Geografi

Tahun 24, Nomor 1, Jan 2019, Hal 25-30

menghitung luas. Hampir semua mahasiswa bisa melakukan interpretasi peta kecuali dalam menentukan luas lahan. Untuk menghitung luas ini hanya terdapat $7(11,66 \%)$ mahasiswa yang benar. Kesalahan hasil perhitungan terletak pada konversi satuan dari $\mathrm{cm} 2$ ke satuan hektar (Ha) atau kilometer2 (Km). Oleh karena itu, dalam perkuliahan sub-tema satuan pengukuran harus lebih diutamakan sehingga mahasiswa tidak akan salah lagi dalam menghitung luas. Kemampuan menginterpretasi peta setingkat lebih tinggi dari pada kemampuan membaca peta.

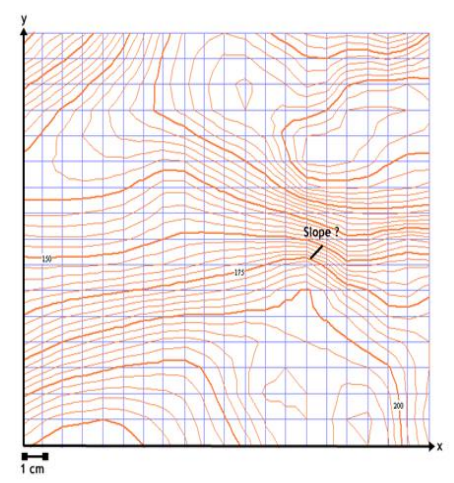

Gambar 2. Contoh peta kontur pada RBI untuk mengukur luas lahan berdasarkan batas kontur.

\section{Menganalisis Peta RBI}

Menganalisis peta (RBI) merupakan tingkatan tersulit dalam menggunakan peta, karena kegiatan itu biasanya memerlukan informasi lain yang ada di luar peta. Jadi pengetahuan geografi fisik dan pengalaman lapangan akan sangat membantu dalam menginterpretasi suatu peta. Pada penelitian ini analisis peta yang dilakukan oleh responden adalah: 1) menentukan batas DAS, 2) menentukan orde sungai, 3) menentukan tipe bentuk lahan, dan 4) menentukan tipe bahaya alam yang potensial di suatu lahan. Ke empat hal itu sudah diajarkan pada perkuliahan kartografi.

Berdasarkan data penelitian diketahui terdapat 17 (28,33\%) mahasiswa yang bisa mengerjakan ke empat hal tersebut dengan memperoleh nilai maksimum (40) dan 25 $(41,66 \%)$ mahasiswa bisa menduga tipe bentuk lahan yang tergambar pada peta, 35 orang sisanya salah dalam menentukan bentuk lahan.

Tabel 5. Kemampuan menggunakan peta RBI mahasiswa Pendidikan Geografi

\begin{tabular}{ccccc}
\hline \multirow{2}{*}{ No. } & Kelas Kemampuan & \multicolumn{2}{c}{ Frekuensi } & \multirow{2}{*}{ Kategori } \\
\cline { 2 - 4 } & & Jumlah & \% & \\
\hline 1 & $0-25$ & 1 & 2 & Sangat rendah \\
\hline 2 & $26-50$ & 3 & 5 & Rendah \\
\hline 3 & $51-75$ & 24 & 40 & Sedang \\
\hline 4 & $>75$ & 32 & 53 & Tinggi \\
\hline & jumlah & 60 & 100 & \\
\hline
\end{tabular}

Berdasarkan pada Tabel 5. diketahui bahwa tingkat kemampuan menggunakan peta RBI 1:25.000 oleh mahasiswa Pendidikan Geografi angkatan 2016 bervariasi, namun kategori kemampuan tinggi menempati urutan pertama, yaitu sebanyak 32 orang (53\%), kemampuan sedang 24 orang (40\%), kemampuan rendah 3 orang $(5 \%)$, dan kemampuan sangat rendah 1 orang $(2 \%)$. 


\section{KESIMPULAN}

1. Dalam kemampuan membaca peta RBI terdapat 36 (76,6\%) mahasiswa yang benar, 15 (25\%) mahasiswa menjawab setengah dan terdapat $8(13,33 \%)$ mahasiswa yang sama sekali tidak bisa mennggambarkan format baku/lay out peta RBI $1: 25.000$, namun masih mampu membaca simbul peta.

2. Kemampuan menginterpretasi peta terdapat kelemahan pada penghitungan luas lahan, untuk menghitung luas ini hanya terdapat $7(11,66 \%)$ mahasiswa yang benar

3. Dalam menganalisis peta RBI, mahasiswa yang bisa mengerjakan ke empat hal tersebut sejumlah 17 (28,33\%) dengan memperoleh nilai maksimum tetapi dalam menduga tipe bentuklahan hanya terdapat $25(41,66 \%)$ yang benar. Ini bisa diartikan mahasiswa belum berpengalam menggunakan peta RBI yang dikaitan dengan pengalaman lapangan.

\section{DAFTAR RUJUKAN}

Arikunto, S. (2002). Prosedur penelitian, suatu pendekatan praktek (Edisi revisi V). Jakarta: Rineka Cipta.

BAKOSURTANAL. (2005).Spesidikasi Geodesi Peta Rupa Bumi. Bogor: Cibinong.

BSN. (2010). SNI6502.4: 2010. Spesifikasi Penyajian Peta Rupa Bumi. Bagian 4: Skala 1 : 250.000. Badan Standarisasi nasional (BSN) Jakarta: Indonesia.

Dahar, RW. (1989). Teori-teori belajar. Jakarta: Erlangga.

Depdagri. (2013). Peraturan Pemerintah Republik Indonesia. Nomor 8 Tahuan 2013 tentang Ketelitian Peta Rencana Tata Ruang. Jakarta: Depdagri.

Fatchan, A. (2004). Penelitian tindakan kelas dan teknik pembuatan proposalnya. Malang: Lemlit-UM.

Keates, J. (1976). Cartographic design and production. London: Longman Ltd.

Muehrcke C, Phillip. (1978). Map use: Reading, analysis, and interpretation. Wisconsin, USA.

Oxtoby P.J. and Brown, A. (1976). Cartographic techniques. The Netherland: I.T.C.

Robinson, A.H. (1953). Elements of cartography. USA: John Wiley \& Sons.

Sijmons, K., Oxtoby, P.J. (1983). Map projection. The Netherland: I.T.C.

Surjosumarto. (1977). Membaca peta. Jakarta.

Saleh, M. (2003). Pengaruh penggunaan peta terhadap prestasi belajar siswa dalam mata pelajaran Geografi di MA. Sumber Bungur Pakong. Malang: Skripsi tidak diterbitkan.

Sumaatmadja, N. (1996). Metodologi pengajaran Geografi. Jakarta: Bumi Aksara.

Suryantoro, A. (2004). Kartografi dasar (Hand Out untuk kalangan mahasiswa). Malang: Universitas Negeri Malang.

Wiriaatmadja, R. (2007). Metode penelitian tindakan kelas (Untuk meningkatkan kinerja guru dan dosen). Bandung: PT. Remaja Rosdakarya. 